Erin Gatza $\cdot$ Craig Y. Okada

\title{
Adjuvant IL-15 does not enhance the efficacy of tumor cell lysate-pulsed dendritic cell vaccines for active immunotherapy of $T$ cell lymphoma
}

Received: 15 November 2004 / Accepted: 25 March 2005/Published online: 15 July 2005

(C) Springer-Verlag 2005

\begin{abstract}
There has been a recent interest in using IL-15 to enhance antitumor activity in several models because of its ability to stimulate $\mathrm{CD} 8^{+} \mathrm{T}$ cell expansion, inhibit apoptosis and promote memory $\mathrm{T}$ cell survival and maintenance. Previously, we reported that C6VL tumor lysate-pulsed dendritic cell vaccines significantly enhanced the survival of tumor-bearing mice by stimulating a potent tumor-specific $\mathrm{CD} 8^{+} \mathrm{T}$ cell response. In this study, we determined whether IL-15 used as immunologic adjuvant would augment vaccine-primed $\mathrm{CD}^{+} \mathrm{T}$ cell immunity against C6VL and further improve the survival of tumor-bearing mice. We report that IL-15 given after C6VL lysate-pulsed dendritic cell vaccines stimulated local and systemic expansion of NK, NKT and $\mathrm{CD}^{+}{ }^{+} \mathrm{CD} 44^{\text {hi }} \mathrm{T}$ cells. IL-15 did not, however, augment innate or cellular responses against the tumor. T cells from mice infused with IL-15 following vaccination did not secrete increased levels of tumorspecific TNF- $\alpha$ or IFN- $\gamma$ or have enhanced C6VL-specific CTL activity compared to $\mathrm{T}$ cells from recipients of the vaccine alone. Lastly, IL-15 did not enhance the survival of tumor-bearing vaccinated mice. Thus, while activated- and memory-phenotype $\mathrm{CD} 8^{+} \mathrm{T}$ cells were dramatically expanded by IL-15 infusion, vaccineprimed $\mathrm{CD} 8{ }^{+} \mathrm{T}$ cells specific for $\mathrm{C} 6 \mathrm{VL}$ were not sig-
\end{abstract}

E. Gatza

Graduate Program in Immunology,

University of Michigan Medical School,

Ann Arbor, MI 48109, USA

Present address: C. Y. Okada $(\square)$

Division of Hospital and Specialty Medicine,

Portland VA Medical Center,

3710 SW US Veterans Hospital Road,

R\&D 54, Portland, OR 97239, USA

E-mail: okadac@ohsu.edu.

Tel.: + 1-503-2208262

Fax: + 1-503-7211024

C. Y. Okada

Department of Internal Medicine,

Division of Hematology-Oncology,

Oregon Health Sciences University,

Portland, OR 97239, USA nificantly expanded. This is the first account of using IL15 as an adjuvant in a therapeutic model of active immunotherapy where there was not a preexisting pool of tumor-specific $\mathrm{CD} 8{ }^{+} \mathrm{T}$ cells. Our results contrast the recent studies where IL-15 was successfully used to augment tumor-reactivity of adoptively transferred transgenic $\mathrm{CD} 8^{+} \mathrm{T}$ cells. This suggests that the adjuvant potential of IL-15 may be greatest in settings where it can augment the number and activity of preexisting tumor-specific $\mathrm{CD} 8^{+} \mathrm{T}$ cells.

Keywords Dendritic cells - Tumor immunity Vaccination · Interleukin-15

Abbreviations NK: Natural killer $\cdot$ NKT: Natural killer T cells - C6VL-DC: DC pulsed with C6VL lysate $\cdot$ MBL-2-DC: DC pulsed with MBL lysate - DLN: Draining lymph node $\cdot$ CLLN: Contralateral lymph node $\cdot h$ : Hour $\cdot d$ : Day

\section{Introduction}

Interleukin-15 was identified and purified based on its abilities to bind the IL-2 receptor $\beta$-chain and to stimulate the proliferation of IL-2-dependent cell lines and antigen-specific $\mathrm{T}$ cell clones, including cytolytic effector cells [11]. It has since been shown that while IL-2 and IL15 share many functions, especially in innate immunity, they can play distinct and contrasting roles in $\mathrm{T}$ cellmediated immune responses [40]. While systemic administration of IL-2 can act as a potent adjuvant to tumor vaccinations and adoptive $\mathrm{T}$ cell transfer immunotherapy strategies [1,34], it also limits the magnitude and duration of $\mathrm{T}$ cell responses through elimination or suppression of responding $\mathrm{T}$ cells $[23,41]$ and interference with $\mathrm{CD} 8^{+}$memory $\mathrm{T}$ cells survival $[21,46]$. High dose IL-2 can also cause severe, dose-limiting toxicities in patients [39]. In contrast, IL-15 rescues T cells from IL-2-mediated activation-induced cell death [23] and 
promotes memory cell generation and maintenance $[2,4$, $13,32,46]$. IL-15 is also essential for the development and activation of NK and NKT cells in vitro [8, 15]. In murine tumor models, IL-15 exhibits a superior therapeutic index [26] and a stronger target-specific accumulation with more rapid clearance from the circulation [20] compared to IL-2. Thus, IL-15 may be an attractive alternative to IL-2 for adjuvant use in immunotherapy.

Three primary goals in the generation of effective immunotherapeutic approaches for tumors are to induce effective tumor-specific cell-mediated responses, promote the survival of antigen-specific T cells, and to induce longlived $\mathrm{T}$ cell memory against the tumor [5]. There are few published reports assessing the effects of IL-15 on CD8 ${ }^{+}$ T cell responses in vivo [7, 16, 43, 46]. However, collective in vitro and in vivo evidence from various groups suggests that IL-15 positively influences the initiation, clonal expansion, contraction and maintenance phases of antigen-specific $\mathrm{CD}^{+}{ }^{+} \mathrm{T}$ cell immunity [38]. Two groups have recently reported the use of IL-15 in adoptive transfer models of tumor therapy. Brentjens et al. [3] showed that genetically targeted $\mathrm{T}$ cells expanded in IL-15 prior to transfer uniquely persisted in tumor-bearing hosts and cleared disseminated B cell tumors. Secondly, Klebanoff et al. [19] demonstrated that systemic administration of IL-15 in addition to $\mathrm{T}$ cell stimulation with an altered peptide ligand following adoptive transfer of antigenspecific transgenic $\mathrm{CD}^{+} \mathrm{T}$ cells improved their in vivo tumor activity. While there have been few accounts of IL15 use in active immunotherapy protocols, the results have supported the hypothesis that IL-15 has strong adjuvant potential. IL-15 augmented the primary antigenspecific $\mathrm{CD}^{+}{ }^{+} \mathrm{T}$ cell response when delivered systemically following peptide-pulsed dendritic cell (DC) vaccine [35], and stimulated long-lived memory $\mathrm{CD} 8^{+}$responses when delivered in a vaccinia vector with an HIV antigen [28]. However, IL-15 in combination with active immunotherapy against tumor has not been reported in a therapeutic model, where there was no preexisting pool of tumor-reactive $\mathrm{CD}^{+}{ }^{+} \mathrm{T}$ cells.

We previously demonstrated that DC pulsed with tumor cell lysates stimulated $\mathrm{CD}^{+} \mathrm{T}$ cell mediated clearance of the murine $\mathrm{T}$ cell lymphoma, C6VL [10], resulting in $\sim 40 \%$ survival of tumor bearing mice. We hypothesized that using IL-15 as an immunologic adjuvant would augment vaccine stimulated $\mathrm{CD} 8^{+}$ $\mathrm{T}$ cell immunity against $\mathrm{C} 6 \mathrm{VL}$, and result in higher levels of survival among vaccine recipients. While IL15 stimulated local and systemic expansion of $\mathrm{NK}$, NKT and $\mathrm{CD}^{+}{ }^{+} \mathrm{CD}_{4}{ }^{\text {hi }} \mathrm{CD} 2 \mathrm{~L}^{+/-} \mathrm{T}$ cells, it did not increase innate or cellular responses against the tumor. Mice infused with IL-15 following active immunization with C6VL lysate-pulsed DC (C6VL-DC) did not have augmented NK lytic activity, tumor-specific secretion of Th1-type cytokines or C6VL-specific CTL activity compared to recipients of the vaccine alone. Correspondingly, the delivery of IL-15 did not enhance the survival of tumor-bearing vaccinated mice. Thus, while IL-15 dramatically expanded activated- and memory- phenotype $\mathrm{CD} 8^{+} \mathrm{T}$ cells following C6VL-DC vaccines, vaccine-primed $\mathrm{CD}^{+} \mathrm{T}$ cells with specificity for C6VL were not significantly or preferentially expanded, and the therapeutic efficacy of DC-based vaccine therapy was not enhanced. These results, along with reports of success in IL-15 use with adoptive transfer tumor therapy, suggest that IL-15 will be most useful as an immunologic adjuvant in settings where there is a preexisting population of tumor-specific $\mathrm{CD}^{+} \mathrm{T}$ cells rather than using it to augment primary $\mathrm{CD}^{+} \mathrm{T}$ cell responses stimulated by active immunotherapy in a tumor-bearing host.

\section{Materials and methods}

Mice

Female $\mathrm{C} 57 \mathrm{Bl} / 6$ mice $\left(\mathrm{H}-2^{\mathrm{b}}\right)$ were purchased from the Jackson Laboratory (Bar Harbor, ME, USA) at 6 weeks of age. The animals were maintained under specific pathogen free conditions according to the guidelines in the Animal Component of Research Protocol implemented in $\mathrm{VA}$ research centers. The mice were between 7 weeks and 9 weeks of age when vaccine protocols were initiated.

\section{Media and cytokines}

AIM-V serum-free media (Invitrogen; Carlsbad, CA, USA) containing $50 \mu \mathrm{M} 2-\mathrm{ME}$ was used to generate DC-based vaccines as described below. C6VL for tumor challenges and all tumor lines used for in vitro assays were grown in complete media (CM), consisting of RPMI 1640 supplemented with 10\% FBS and $50 \mu \mathrm{M} 2$ ME. Murine rGM-CSF (sp. act. $\geq 5.0 \times 10^{6} \mathrm{U} / \mathrm{mg}$ ) and murine rIL-4 $\left(6.1 \times 10^{8} \mathrm{U} / \mathrm{mg}\right)$ were purified from over expressing cell lines generated in our laboratory. Human rIL-2 $\left(18.0 \times 10^{6} \mathrm{U} / \mathrm{mg}\right)$ was obtained from Chiron Corp. (Emeryville, CA, USA). Human rIL-15 $\left(2.39 \times 10^{8} \mathrm{U} / \mathrm{mg}\right.$; endotoxin levels $<2.65 \mathrm{EU} / \mathrm{mg}$ protein) was kindly provided by Amgen Corporation (Seattle, WA, USA).

\section{Cell lines}

C6VL $\left(\mathrm{H}-2^{\mathrm{b}}\right)$ is a radiation-induced $\mathrm{T}$ cell thymoma of $\mathrm{C} 57 \mathrm{Bl} / \mathrm{Ka}$ background and expresses TCR $-\alpha \beta$, Thy 1.2 , $\mathrm{CD} 3, \mathrm{CD} 4$, and $\mathrm{H}-2 \mathrm{D}^{\mathrm{b}}$ [27]. C6VL does not express MHC Class II or Fas [29]. MBL-2 $\left(\mathrm{H}-2^{\mathrm{b}}\right)$ is a T cell lymphoma cell line of $\mathrm{C} 57 \mathrm{Bl} / 6$ origin (provided by I. L. Weissman, Stanford, CA, USA) that was used as a control $\mathrm{T}$ cell lymphoma lysate and control tumor for in vitro restimulation. YAC- $1\left(\mathrm{H}-2^{b}\right)$ is a Maloney murine leukemia virus-induced murine $\mathrm{T}$ cell lymphoma line of A/Sn origin that is susceptible to NK-mediated lysis [17, 18] and was purchased from the American Type Culture Collection (Manassas, VA, USA). 


\section{Antibodies}

FITC-conjugated anti-CD4 (GK1.5, Rat $\left.\operatorname{IgG}_{2 \mathrm{~b}}, \kappa\right)$, antiNK1.1 (PK136, Mouse $\operatorname{IgG}_{2 \mathrm{a}}, \kappa$ ), anti-CD44 (IM7, Rat $\left.\mathrm{IgG}_{2 \mathrm{~b}}, \kappa\right)$, anti-CD122 (5H4, Rat $\left.\operatorname{IgG}_{2 \mathrm{a}}\right)$, PE-conjugated anti-CD8b.2 (53-5.8, Rat IgG 1 ), anti-CD4 (H129.19, Rat $\mathrm{IgG}_{2 \mathrm{a}}$ ), anti-CD25 (3C7, Rat $\left.\mathrm{IgG}_{2 \mathrm{~b}}, \kappa\right)$, anti-CD44 (IM7, Rat $\left.\operatorname{IgG}_{2 \mathrm{~b}}, \kappa\right)$, anti-CD69 (H1.2F3, Hamster IgG1), antiCD43 (1B11, Rat $\mathrm{IgG}_{2 \mathrm{a}}, \kappa$ ), anti-CD62L (MEL-14, Rat $\left.\operatorname{IgG}_{2 \mathrm{a}}, \kappa\right)$, and biotinylated anti-CD8b.2 (53-5.8, Rat $\mathrm{IgG}_{1}$ ) and anti-TCR $\beta$-chain (H57-597, Hamster $\mathrm{IgG}$ ) were used for phenotypic analysis (all from BD Biosciences, San Diego, CA, USA). Streptavidin-PerCPCy5.5, Fc block and all isotype antibody controls were also purchased from BD Biosciences. ELC-Ig chimera was kindly provided by Dr Timothy Springer (Harvard University, Boston, MA, USA). PE-conjugated goat antihuman IgG was purchased from Southern Biotechnology Associates (Birmingham, AL, USA).

\section{Tumor challenge}

Two days prior to tumor challenge, an aliquot of tumor cells was thawed and cultured in CM for $48 \mathrm{~h}$. The cells were collected by centrifugation, washed and counted using a hemocytometer. The viability of the tumor cells prior to tumor challenge was generally $>98 \%$ as determined by trypan blue exclusion. A lethal number of tumor cells in $500 \mu \mathrm{l}$ HBSS was injected i.p. The $\mathrm{LD}_{100}$ for C6VL was 1,000 cells. Mice received their first vaccination 1 day after receiving their tumor challenge. Groups of ten mice were used for survival analysis and were monitored for 60 days. Survival curves were constructed according to the Kaplan-Meier method [14]. Statistical differences between vaccine groups was determined using the log-rank test [30], and was significant when $P<0.05$.

\section{Generation of bone marrow-derived DC}

Bone marrow cells were flushed from the femurs and tibias of C57BL/6 mice, depleted of erythrocytes, and cultured for 5 days in AIM-V serum-free media containing $50 \mu \mathrm{M}$ 2-ME and $10 \mathrm{ng} / \mathrm{ml} \mathrm{rGM-CSF}$ and rIL-4 as previously described [10]. Nonadherent cells were enriched for DC using one of two methods. They were harvested by gentle pipetting and suspended in AIM-V to a density of $5.0 \times 10^{6}$ cells $/ \mathrm{ml}$, overlayed over media containing $14.5 \%$ $(\mathrm{w} / \mathrm{v})$ metrizamide [9] or resuspended in 11.5\% Optiprep (iodixanol, Sigma, St. Louis, MO, USA) in Optiprep diluent $(0.88 \mathrm{w} / \mathrm{v} \mathrm{NaCl}, 1 \mathrm{mM}$ EDTA, $0.5 \% \mathrm{w} / \mathrm{v}$ bovine serum albumin, $10 \mathrm{mM}$ hepes- $\mathrm{NaOH}, \mathrm{pH}$ 7.4) and placed under HBSS [36]. The cells were centrifuged at $600 \times g$ for $15 \mathrm{~min}$ and the cells at the interface collected, washed and analyzed by flow cytometry for expression of cell surface markers as previously described [10]. Cells from each preparation were $\geq 80 \%$ positive for the co-expression of
MHC II, CD11c, CD54, CD80 and CD86 (data not shown). The DC preparations did not have cells that expressed CD3 or CD19.

Ag pulsing of DC, Immunizations and IL-15 administration

After purification, DCs were resuspended to $1.0 \times 10^{6}$ cells $/ \mathrm{ml}$ in AIM-V media containing freeze-thaw cell lysate from either C6VL or MBL-2 (control) as previously described [10]. The DC were pulsed with lysates from three tumor cells per DC. After incubating for $18 \mathrm{~h}$, the DC were collected, washed three times and suspended in HBSS at $5.0 \times 10^{6}$ cells $/ \mathrm{ml}$. $5.0 \times 10^{5}$ lysatepulsed DC were injected s.c. in the right flank of tumorbearing mice every 10 days. Mice used for lymphocyte immunophenotype analysis, CTL and cytokine secretion assays and as lymphocyte transfer donors were immunized twice. Mice monitored for survival were immunized three times. $0.5 \mu \mathrm{g}$ rhIL-15 diluted in HBSS containing $1 \%$ naïve mouse serum was administered s.c. at the vaccine site beginning 1 day after each vaccine and continued every $12 \mathrm{~h}$ for five consecutive days. Mice that did not receive IL-15 were infused with only the diluent on the same schedule.

\section{Immunophenotype of DLN, CLLN and splenocytes}

Eighteen hours after the last IL-15 infusion, DC vaccine primed draining lymph node (DLN, right inguinal), contralateral lymph node (CLLN, left inguinal) and spleens were harvested from tumor-challenged mice ( $n=6-20$ per group). Tumor-challenged mice treated with diluent or IL-15 only were included as controls. Lymph nodes and spleens were processed separately into single-cell suspensions and then passed through $70-\mu \mathrm{m}$ nylon mesh filters. Splenocytes were depleted of erythrocytes using Red Cell Lysis Buffer (Sigma, St. Louis, MO,USA). Pooled DLN, CLLN and splenocyte populations from each group were washed twice with PBS containing $0.5 \%$ mouse serum and $1.0 \%$ BSA (FACS Buffer). $1.5-3.0 \times 10^{5}$ cells per sample were seeded in wells of round-bottom 96-well plates and prestained with $\mathrm{Fc}$ block $\left(0.5 \mu \mathrm{g} / 10^{6}\right.$ cells) for $20 \mathrm{~min}$ on ice. Cells were stained with FITC- $\left(1.0 \mu \mathrm{g} / 10^{6}\right.$ cells $), \quad$ PE- $(0.5 \mu \mathrm{g} /$ $10^{6}$ cells $)$ and biotin-conjugated $\left(1.0 \mu \mathrm{g} / 10^{6}\right.$ cells $)$ antibodies or isotype controls in $50 \mu \mathrm{l}$ FACS Buffer for $30 \mathrm{~min}$ on ice. Following two washes in $200 \mu \mathrm{l}$ FACS Buffer, each sample was incubated with StreptavidinPerCP-Cy5.5 $\left(0.5 \mu \mathrm{g} / 10^{6}\right.$ cells $)$ for $20 \mathrm{~min}$ on ice to detect biotinylated antibodies. The recombinant CCR7 ligand, ELC-Ig chimera [22], was used to detect CCR7 expression. After prestaining with Fc block, cells were incubated with purified ELC-Ig supernatant $(50 \mu \mathrm{l} /$ sample) for $1 \mathrm{~h}$ on ice followed by incubation with PEconjugated goat antihuman $\operatorname{IgG}\left(0.5 \mu \mathrm{g} / 10^{6}\right.$ cells $)$ for $30 \mathrm{~min}$ on ice. All samples were washed three times with 
FACS buffer, fixed in $50 \mu \mathrm{l}$ of $2 \%$ paraformaldehyde $(\mathrm{w} /$ v), and analyzed by flow cytometry using a FACScan (BD Biosciences; San Jose, CA, USA) and CellQuest software (BD Biosciences). Amorphous gates were loosely drawn around viable cell populations based on forward and side scatter plots to exclude cellular debris from analysis, and 10,000 gated events were collected per sample. In some experiments, $\mathrm{CD} 8^{+} \mathrm{T}$ cells were purified by negative selection using the MACS CD8 ${ }^{+} \mathrm{T}$ Cell Isolation Kit (Miltenyi Biotec; Auburn, CA, USA) prior to staining. Flow cytometry showed that $>98 \%$ of the resulting cell population expressed CD8. NK cells were defined as cells that were NK1.1 ${ }^{+}, \alpha \beta \mathrm{TCR}^{-}$; NKT cells as $\mathrm{NK} 1.1^{+}, \alpha \beta \mathrm{TCR}^{+} ; \alpha \beta \mathrm{T}$ cells as NK1.1 ${ }^{-}$, $\alpha \beta \mathrm{TCR}^{+}$; and CD4 and CD8 T cells as $\mathrm{CD}^{+} \alpha \beta \mathrm{TCR}^{+}$ and $\mathrm{CD} 8 \mathrm{~b}^{+} \alpha \beta \mathrm{TCR}^{+}$, respectively.

\section{In vitro cytokine secretion assay}

Draining lymph nodes and splenocytes from each treatment group ( $n=5$ per group) were collected as described above. For each treatment group, $5.0 \times 10^{5}$ of each cell population were plated in triplicate wells of a 96-well plate with either $1.0 \times 10^{5}$ per well mitomycin-C-treated C6VL or MBL-2, $1.0 \mu \mathrm{g} / \mathrm{ml}$ ConA, or with no stimulation (media only) and incubated at $37^{\circ} \mathrm{C}$ for $72 \mathrm{~h}(200 \mu \mathrm{l} /$ well). Wells containing only mitomycin-C-treated C6VL or MBL-2 were included to control for cytokine secretion by stimulator cells. Concentrations of IFN- $\gamma$, TNF- $\alpha$, IL-4 and IL-2 in the culture supernatants were assayed using the BD Murine Th1/Th2 Cytometric Bead Array System (Becton Dickinson, San Jose, CA, USA). A 1x standard solution of mouse Th1/Th2 cytokines was prepared as described in the manufacturer's protocol. The remainder of the assay was performed and analyzed as described by the manufacturer, except all volumes were reduced by one-half. The linear range of detection for each cytokine monitored was $20-2,500 \mathrm{pg} / \mathrm{ml}$. Data are represented as the mean of triplicate samples \pm SD. Statistics between groups were measured using the Student's $t$ test, and significance was reached when $P<0.05$.

In vitro detection of NK- and CTL-mediated lysis

Draining lymph nodes, spleen and peritoneal lavage cells were harvested from mice treated with C6VL-DC, C6VL$\mathrm{DC}+\mathrm{IL}-15$, IL-15 or diluent $18 \mathrm{~h}$ following their last IL15 infusion and processed as described above. Cells were restimulated in vitro for 5 days at a density of $5.0 \times 10^{6} / \mathrm{ml}$ $(1.0 \mathrm{ml}$ per well in 24-well plates) with irradiated C6VL (2000 Rad) in CM containing $20 \mathrm{U} / \mathrm{ml}$ rhIL-2. Following restimulation, viable cells were enriched over Lympholyte M density medium (Cedarlane Laboratories Ltd.; Hornby, ON, Canada) per the manufacturer's protocol. Duplicate samples of DLN, splenocytes and lavage cells from each group were plated in round bottom 96-well plates using threefold serial dilutions at a starting con- centration of $5.0 \times 10^{6}$ cells $/ \mathrm{ml}$ in CM. C6VL or control MBL-2 cells were labeled for 3 min with Vybrant 3,3'dioctadecyloxacarbocyanine perchlorate (DiO) Cell Labeling Solution (Molecular Probes; Eugene, OR, USA) per manufacturer's protocol for nonadherent cells and $2.0 \times 10^{4}$ cells were added to each well in $100 \mu \mathrm{l} \mathrm{CM}$, resulting in effector-to-target ratios (E:T) of 50:1, 16.7:1 and 5.6:1 in a total volume of $200 \mu \mathrm{l} /$ well. To measure NK-mediated lysis, DLN and splenocytes from each group were pooled and plated in duplicate without in vitro stimulation in flat-bottom 48-well plates using fourfold serial dilutions starting at a concentration of $8.0 \times 10^{6} \mathrm{cells} / \mathrm{ml}$ in $200 \mu \mathrm{l}$ per well. $2.0 \times 10^{4} \mathrm{C} 6 \mathrm{VL}$ or NKsusceptible YAC-1 cells that were labeled as indicated above were added to each well in $200 \mu \mathrm{CM}$, resulting in E:T of $80: 1,20: 1$ and $5: 1$ in a total volume of $400 \mu \mathrm{l} /$ well. Wells containing only DiO-labeled target cells were included as controls for spontaneous death of target cells for both assays. The cells were incubated for $4 \mathrm{~h}$ (CTL lysis) or $16 \mathrm{~h}$ (NK lysis; based on protocol reported by Kennedy et al. [15]) at $37^{\circ} \mathrm{C}$ in a $5 \% \mathrm{CO}_{2}$ incubator and then $10 \mu \mathrm{l}$ of PI cell staining solution (BD Biosciences; San Jose, CA, USA) was added to each sample and incubated an additional 15 min at RT protected from light. To determine percent target cell death in each well, the percent of 7,500 gated $\mathrm{DiO}^{+}$C6VL or MBL-2 target cells that were also positive for PI staining was measured by flow cytometry (FACScan, BD Biosciences, San Jose, CA, USA). The gate to collect $\mathrm{DiO}^{+}$target cells was set on a plot of forward scatter versus $\mathrm{DiO}$ intensity to include viable and dead $\mathrm{DiO}^{+}$C6VL, MBL-2 or YAC-1 cells and exclude all effector cells. Percent lysis for each sample was calculated as $[(\%$ death of target cells plated with effectors $)-(\%$ death of target cells without effector cells)]. Data are represented as the mean of duplicate samples \pm SD. Statistics between groups were measured using the Student's $t$ test. Statistical significance was reached when $P<0.05$. This flow cytometric cytotoxicity assay was previously reported to be suitable for measuring both T cell and NK-mediated cytotoxicity with sensitivity comparable to that observed using the standard ${ }^{51} \mathrm{Cr}$ release assay [31], and yields highly reproducible results.

Transfer of draining lymphocytes from vaccineand IL-15-treated mice to naïve recipients

Groups of 13 tumor-challenged donor mice were vaccinated twice with C6VL-DC or the control vaccine, MBL-2 lysate-pulsed DC (MBL-2-DC). IL-15 was administered following each vaccine as described above. Groups of 11 mice vaccinated with C6VL-DC or MBL2-DC without IL-15 infusion were included as positive and negative controls, respectively. Eighteen hours after the last IL-15 infusion, DLN from each group were harvested, pooled and prepared as described above. DLN were mixed with 5000 C6VL cells (five times the lethal dose, thawed for tumor challenge as above) and injected into the peritoneum of ten naïve recipient mice 
per group. Each naïve recipient received either a number of cells equivalent to one donor's DLN $\left(3.2 \times 10^{6}\right.$, C6VLDC and MBL-2-DC DLN; or $6.7 \times 10^{6}$, C6VL-DC + IL15 and MBL-2-DC+ IL-15 DLN) or a number of cells from C6VL-DC + IL-15 or MBL-2-DC + IL-15 recipient DLN that resulted in the transfer of a number of CD8 ${ }^{+}$ $T$ cells that matched those transferred in one DLN from C6VL-DC and MBL-2-DC donors $\left(1.7 \times 10^{6}\right.$ total cells or $5.9 \times 10^{5} \mathrm{CD}^{+}$, per recipient). Recipient mice were monitored for survival for 60 days following tumor challenge.

\section{Results}

\section{IL-15 increases DLN, CLLN and spleen cellularity}

Tumor bearing mice were immunized twice with C6VL lysate pulsed DC with each immunization followed by IL15 injections. IL-15 was delivered subcutaneously to avoid administering IL-15 to the same site as the tumor (i.p.) and to potentially augment the expansion and survival of vaccine-primed $\mathrm{CD} 8^{+} \mathrm{T}$ cells in the DLN. Tumor-bearing mice injected with C6VL-DC, IL-15 or diluent alone were included as controls. Eighteen hours following the last IL-15 infusion, the draining lymph nodes (DLN), contralateral lymph nodes (CLLN) and spleens were harvested and analyzed. The lymphocyte viability did not differ among treatment groups (data not shown). C6VL-DC vaccinations alone did not significantly increase DLN cellularity compared to untreated (naïve) tumor-bearing mice $(P=0.057)$ (Fig. 1). However, the combination of C6VL-DC vaccinations and IL15 infusion (C6VL-DC + IL-15) significantly increased the number of DLN cells, raising it nearly 3.5 -fold compared to C6VL-DC vaccine recipients $(P=0.010)$. Similarly, there was an increase in the number of cells isolated from CLLN and spleens of mice treated with C6VL$\mathrm{DC}+\mathrm{IL}-15$ compared to C6VL-DC $(P=0.05$ and 0.012 , respectively), indicating that the IL-15 had a moderate systemic, as well as a local, effect. IL-15 injections alone increased cell numbers in the DLN and CLLN $(P=0.015$ and 0.045 , respectively, compared to naïve mice), but not in the spleen $(P=0.24)$.

C6VL-DC vaccines plus IL-15 synergistically increases the absolute numbers of NK, NKT and $\mathrm{CD} 8^{+} \mathrm{T}$ cells in DLN

The cellular composition of DLN, CLLN and spleens from mice vaccinated and infused with IL-15 was analyzed by flow cytometry. Subcutaneous IL-15, alone or in combination with C6VL-DC vaccines, increased the percentages of $\mathrm{NK}$ and $\mathrm{CD} 8^{+} \mathrm{T}$ cells in the DLN, CLLN and spleens of mice (Table 1 and Fig. 2a). In addition, increased percentages of NKT and total $\alpha \beta$ T cells were evident in the DLN, but not the CLLN or the spleen (Table 1). The increase in

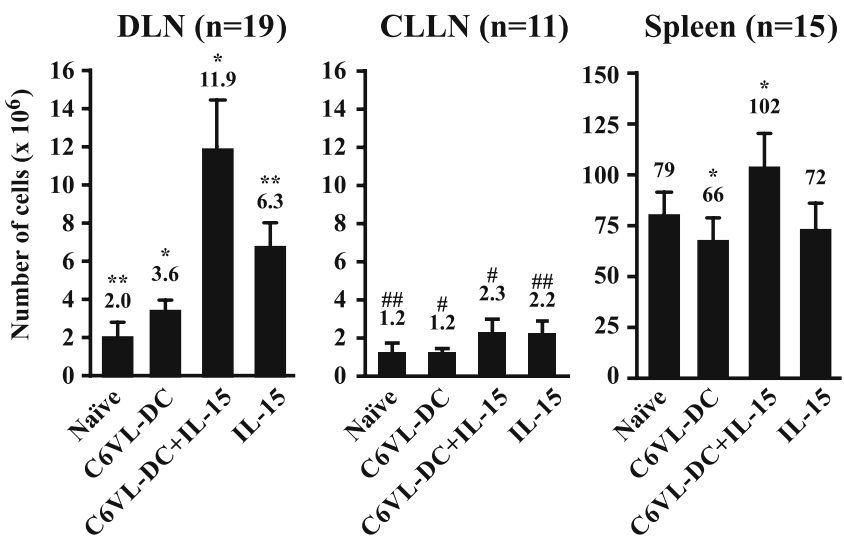

Fig. 1 Interleukin-15 infusion results in increased cell numbers in the DLN, CLLN and spleen. Mice bearing a lethal number of C6VL cells (i.p.) were vaccinated twice s.c. with 5.0 $10^{5}$ C6VL-DC or HBSS (control). $0.5 \mu \mathrm{g}$ rhIL-15 was administered s.c. at the vaccine site every $12 \mathrm{~h}$ for 5 days following each vaccination. Mice not receiving IL-15 were infused with only the diluent. Eighteen hours following the last infusion, DLN, CLLN and spleens were harvested from mice and viable cells enumerated. Bars represent the average number of cells $\left(\times 10^{6}\right)$ isolated per DLN, CLLN or spleen ( $n=3-10 \mathrm{mice} /$ group) in 2 (CLLN) or 4 (DLN and spleen) independent experiments \pm SD. $P$-values were calculated using a 2-sample Student's $t$-test $\left({ }^{*} P<0.012 ;{ }^{* *} P=0.015,{ }^{\#, \# \#} P<0.05\right)$

$\mathrm{CD}^{+} \mathrm{T}$ cells observed in $\mathrm{IL}-15$ recipients was accompanied by a compensatory decrease in the percentage of $\mathrm{CD}^{+}{ }^{+} \mathrm{T}$ cells at all three sites. The effect of IL-15 infusion on the cellular composition of the DLN was more evident when the absolute numbers of each population was compared. In the DLN, C6VL-

Table 1 S.c. IL-15 has local and systemic effects on the cellular compostion of the DLN, CLLN and spleens of recipient mice ${ }^{\mathrm{a}}$

\begin{tabular}{lccccc}
\hline Treatment & $\mathrm{NK}$ & $\mathrm{NKT}^{\mathrm{b}}$ & $\alpha \beta \mathrm{T}^{\mathrm{b}}$ & $\mathrm{CD} 4^{+\mathrm{b}}$ & $\mathrm{CD} 8^{+\mathrm{b}}$ \\
\hline DLN: & & & & & \\
Naïve & 0.60 & 1.03 & 54.5 & 27.0 & 28.9 \\
C6VL-DC & 0.57 & 0.99 & 50.5 & 24.0 & 23.8 \\
C6VL-DC+ IL-15 & 1.37 & 2.42 & 60.9 & 18.7 & 38.6 \\
IL-15 only & 1.21 & 2.17 & 60.1 & 19.8 & 38.3 \\
CLLN: & & & & & \\
Naïve & 0.60 & 1.03 & 60.0 & 27.0 & 28.9 \\
C6VL-DC & 0.67 & 1.28 & 66.3 & 35.0 & 31.6 \\
C6VL-DC+ IL-15 & 1.01 & 1.12 & 69.5 & 25.8 & 41.8 \\
IL-15 only & 0.91 & 0.73 & 66.6 & 26.2 & 42.7 \\
Spleen: & & & & & \\
Naïve & 3.12 & 1.46 & 52.2 & 25.6 & 23.0 \\
C6VL-DC & 3.37 & 2.02 & 48.7 & 23.7 & 21.5 \\
C6VL-DC+ IL-15 & 5.60 & 2.02 & 50.3 & 15.4 & 30.1 \\
IL-15 only & 3.66 & 1.84 & 48.5 & 16.2 & 27.4 \\
\hline
\end{tabular}

${ }^{\mathrm{a}}$ Cells were obtained from DLN, CLLN and spleens of mice in each treatment group 1d following the last IL-15 infusion, and analyzed by flow cytometry as described in Materials and methods. Numbers indicate the average percent of total cells in replicate samples. Data shown is representative of 4 independent experiments of $n=5-6$ / group

${ }^{\mathrm{b}}$ Cell populations categorized based on marker staining as indicated in Materials and methods 

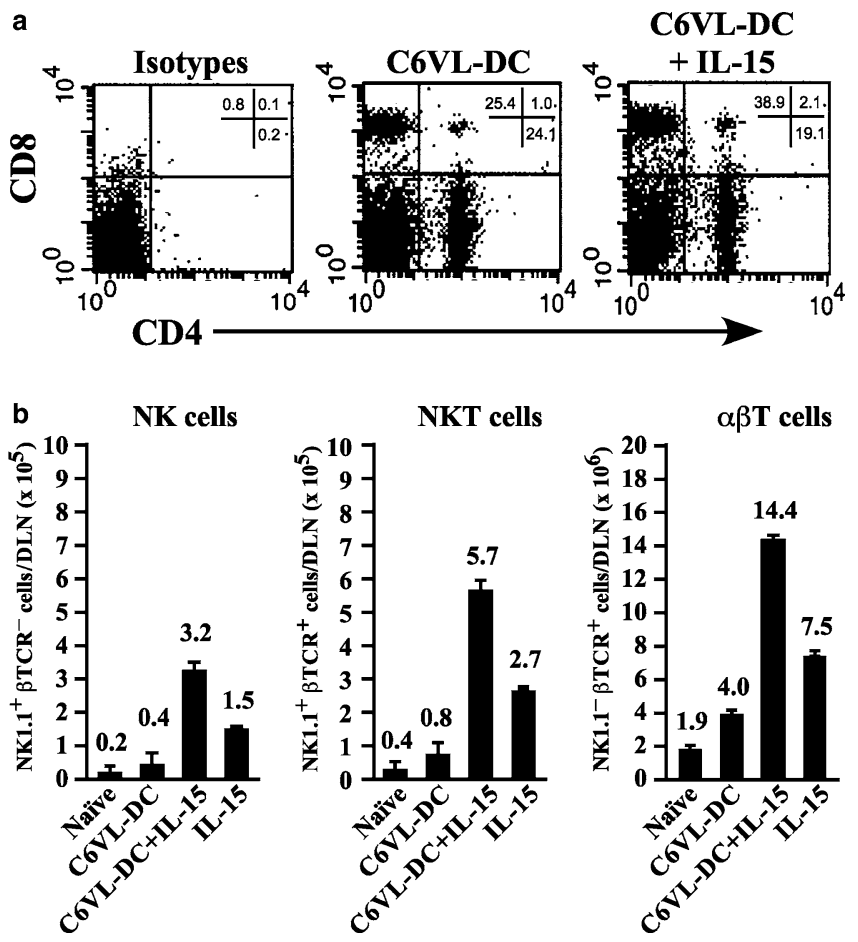

c
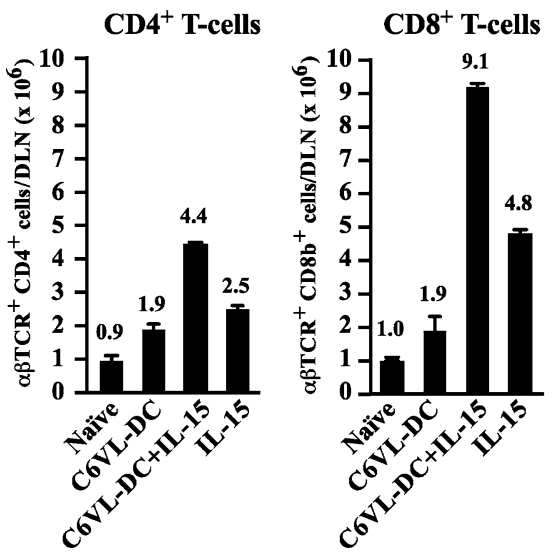

d

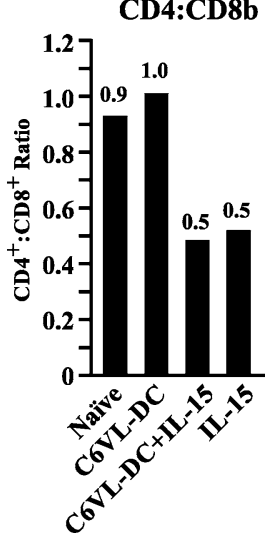

Fig. 2 Recipients of s.c. IL-15 have increased numbers of NK, NKT and $T$ cells in their DLN. Tumor-bearing mice were vaccinated twice s.c. with $5.0 \times 10^{5}$ C6VL-DC or HBSS only. Mice were infused s.c. with IL-15 or diluent only every $12 \mathrm{~h}$ for 5 days after each vaccine. Eighteen hours following the last infusion, DLN were harvested and analyzed by flow cytometry for cell surface expression of markers indicative of (b) NK, NKT, and $\alpha \beta$ T cells; or (a) and (c) $\mathrm{CD}^{+}$and $\mathrm{CD}{ }^{+} \mathrm{T}$ cell subsets as described in Materials and methods. Average absolute numbers of each cell type per DLN were calculated as [(percentage of total cells staining positive $\times$ number of viable cells isolated) $/ n$ of mice per group]. a Representative primary flow cytometry data monitoring the percents of CD4 and CD8 T cells in the DLN of C6VL-DC recipients $+/-$ IL-15. b and c Bars represent the average absolute numbers of cell types in the DLN of each group $(n=5-10$ mice/ group) in four independent experiments \pm SD. d Bars represent the ratio of $\mathrm{CD}^{+}{ }^{+}$to $\mathrm{CD} 8{ }^{+} \mathrm{T}$ cells in the DLN of each group

DC+ IL-15 treatment resulted in a 8.0-fold increase in NK, 7.1-fold increase in NKT, and a 3.6-fold increase in $\alpha \beta \mathrm{T}$ cells per DLN compared to recipients of the
C6VL-DC vaccine alone (Fig. 2b). In addition, CD4 ${ }^{+}$ and $\mathrm{CD}^{+}{ }^{+} \mathrm{T}$ cell numbers were 2.3 - and 4.8 -fold higher, respectively, in recipients of C6VL-DC+ IL-15 compared to recipients of the C6VL-DC vaccine alone (Fig. 2c). C6VL-DC+IL-15 treatment stimulated less dramatic increases in NK, NKT, $\alpha \beta \mathrm{T}$ cell, and $\mathrm{CD} 8^{+}$ $\mathrm{T}$ cell numbers in the CLLN (2.7-, 1.8-, 2.1-, and 2.7fold increases, respectively) and spleens (1.9-, 1.2-, 1.2-, and 1.6-fold increases) compared to the DLN (data not shown). IL-15 infusions without concomitant C6VL-DC vaccination resulted in intermediate increases in each cell population compared to recipients of both treatments. Despite varying magnitudes of $\mathrm{CD}^{+} \mathrm{T}$ cell expansion among the DLN, CLLN and spleen, however, IL-15 infusion with or without concomitant C6VL-DC vaccination resulted in a decreased $\mathrm{CD} 4^{+}: \mathrm{CD} 8{ }^{+} \mathrm{T}$ cell ratio at each site, with ratios ranging from $0.48-0.61$ compared to $1.0-1.1$ in naïve mice or mice treated with C6VL-DC vaccines alone (Fig. 2d and data not shown).

IL-15 infusion increases numbers of activatedor memory-phenotype $\mathrm{CD} 8{ }^{+} \mathrm{T}$ cells in DLN

$\mathrm{CD} 8^{+} \mathrm{T}$ cells were purified from the DLN of each treatment group by negative selection and were stained for the activation marker, CD44, expression in combination with several other activation markers CD62L, CD122, CCR7, CD43, and CD69, to further characterize the influence of IL-15 infusion on the $\mathrm{CD} 8^{+} \mathrm{T}$ cell population in the DLN. Mice that were infused with IL15 alone or in conjunction with C6VL-DC vaccines had significantly higher percents of $\mathrm{CD} 8^{+} \mathrm{CD} 44^{\text {hi }}$ cells in their DLN compared to tumor-bearing mice that received HBSS or C6VL-DC vaccines only (Fig. 3b left panel), resulting in 5.8- and 7.6-fold increases in the absolute numbers of CD ${ }^{+} \mathrm{CD} 44^{\mathrm{hi}} \mathrm{T}$ cells, respectively (Fig. 3b, right panel). Among the $\mathrm{CD} 8^{+} \mathrm{CD} 44^{\text {hi }}$ population, both $\mathrm{CD} 62 \mathrm{~L}^{+}$and $\mathrm{CD} 62 \mathrm{~L}^{-}$cells were expanded (Fig. 3a, c), resulting in 2.1- and 3.2-fold increases in the percents of $\mathrm{CD} 44^{\mathrm{hi}} \mathrm{CD}_{2} \mathrm{~L}^{+}$and $\mathrm{CD} 44^{\mathrm{hi}} \mathrm{CD} 62 \mathrm{~L}^{-}$ $\mathrm{CD} 8^{+} \mathrm{T}$ cells, respectively, when mice were treated with C6VL-DC + IL-15 compared to C6VL-DC alone. While the $\mathrm{CD} 44^{\mathrm{hi}} \mathrm{CD} 62 \mathrm{~L}^{-}$phenotype has been used to indicate populations of effector $\mathrm{CD} 8^{+} \mathrm{T}$ cells, we could not detect a concomitant decrease in CCR7 or increase in CD43 expression to further indicate that these were indeed effector $\mathrm{CD} 8^{+} \mathrm{T}$ cells. In contrast, increases in $\mathrm{CD} 44^{\mathrm{hi}} \mathrm{CD} 122^{+}, \mathrm{CD} 44^{\mathrm{hi}} \mathrm{CCR} 7^{+}, \mathrm{CD} 44^{\mathrm{hi}} \mathrm{CD} 69^{\mathrm{int}}$ $\mathrm{CD} 44^{\mathrm{hi}} \mathrm{CD} 25^{\mathrm{int}}$ and $\mathrm{CD} 44^{\mathrm{hi}} \mathrm{CD} 43^{-} \mathrm{CD}{ }^{+} \mathrm{T}$ cells were observed upon IL-15 infusion (Fig. 3d and data not shown), consistent with the phenotype of $\mathrm{CD}^{+}$central memory T cells [22]. Expansion of these cells was greater in recipients of both C6VL-DC vaccines and IL-15 infusion compared to recipients of either treatment alone and occurred irrespective of the presence of tumor in the peritoneum of recipient mice (data not shown). The effects of IL-15 infusion on the percents of CD8 ${ }^{+}$ 

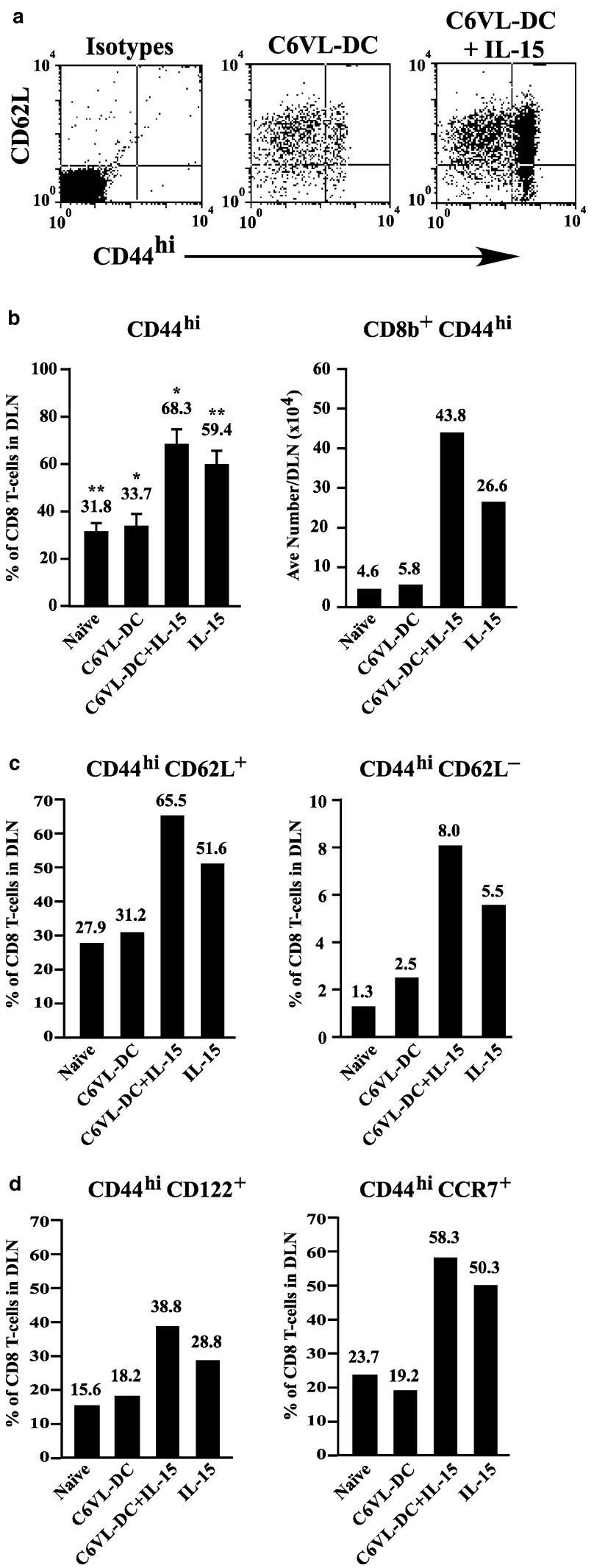

CD $44^{\text {hi }}$ cells in the CLLN and spleen were also evident (data not shown), although the change in absolute number of the cells was of lesser magnitude than in the DLN.
Fig. 3 Antigen-activated or memory-phenotype $\mathrm{CD} 8^{+} \mathrm{T}$ cells are expanded by IL-15 infusion. Groups of 10 (+ IL-15) or 20 (no IL15) tumor-bearing mice were vaccinated and infused with IL-15 as indicated in the Materials and methods. Eighteen hours following the last IL-15 injection, DLN were harvested and CD8 ${ }^{+} \mathrm{T}$ cells purified by negative selection. The $\mathrm{CD} 8^{+} \mathrm{T}$ cells were stained for cell surface expression of CD8b (PerCP-Cy5.5) and CD44 (FITC) alone (b), or in combination with PE-conjugated CD62L, CD122, or CCR7 (a-c) and analyzed by flow cytometry. Bars indicate (b) the average (\%) (left) and absolute number (right) of $\mathrm{CD} 8 \mathrm{~b}^{+}$ CD44 ${ }^{\text {hi }}$ cells per DLN in each treatment group, or c, d the percentage of $\mathrm{CD} 8 \mathrm{~b}^{+}$cells in the DLN that are both CD44hi and $\mathrm{CD} 62 \mathrm{~L}^{+/-}, \mathrm{CD} 122^{+}$or $\mathrm{CCR} 7^{+} . P$ values were calculated using a two sample Student's $t$ test $\left(*\right.$ and $\left.{ }^{* *} P<0.0001\right)$

Tumor-specific secretion of cytokines is not enhanced by s.c. IL-15 infusion

To evaluate whether IL-15 infusions augmented tumorspecific vaccine-primed cellular immunity or innate clearance of C6VL, groups of 5-6 mice were immunized twice with C6VL-DC alone or with s.c. IL-15 infusion. Mice treated with only IL-15 or its diluent were included as controls. Eighteen hours following the last IL-15 infusion, DLN and spleens were harvested from each group and analyzed in vitro for C6VL-specific cytokine release and CTL- and NK-mediated killing of C6VL.

Consistent with our previous findings [10], DLN cells from C6VL-DC vaccinated mice secreted significant amounts of Th1-type cytokines, TNF- $\alpha$ and IFN$\gamma$ compared to IL-4 (Fig. 4, left panel). The secretion of the cytokines was tumor-specific, as their amounts were significantly lower upon in vitro stimulation control MBL-2 tumor. DLN lymphocytes from recipients that were treated with IL-15 in conjunction with C6VL-DC vaccines also secreted TNF- $\alpha$ and IFN- $\gamma$ at high levels (Fig. 4, right panel). Secretion of TNF- $\alpha$ and IFN- $\gamma$ by C6VL-DC + IL-15 DLN cells were also significantly increased upon stimulation with C6VL compared to MBL-2. However, addition of IL-15 to C6VL-DC vaccine therapy did not significantly increase the secretion of tumor-specific TNF- $\alpha$ and IFN$\gamma$ by bulk draining lymph node cells compared to treatment of the mice with C6VL-DC alone $(P$ values of 0.30 and 0.062 for TNF- $\alpha$ and IFN- $\gamma$ secretion, respectively). Similarly, while high levels of tumorspecific $\mathrm{TNF}-\alpha$ and IFN- $\gamma$ were secreted by splenocytes from C6VL-DC+ IL-15 recipients upon stimulation with C6VL compared to MBL-2, the levels were not significantly higher than those secreted by splenocytes from recipients of C6VL-DC alone (data not shown). Secretion of IFN- $\gamma$, TNF- $\alpha$ and IL- 4 by DLN or splenocytes from tumor-bearing mice treated with only IL- 15 or diluent and secretion of IL-2 by any of the groups were below the limits of detection of the assay ( $\leq 20.0 \mathrm{pg} / \mathrm{ml}$, data not shown). Similarly, secretion of the cytokines by mitomycin C-treated C6VL or MBL-2 stimulator cells was not detected (data not shown). 
C6VL-DC
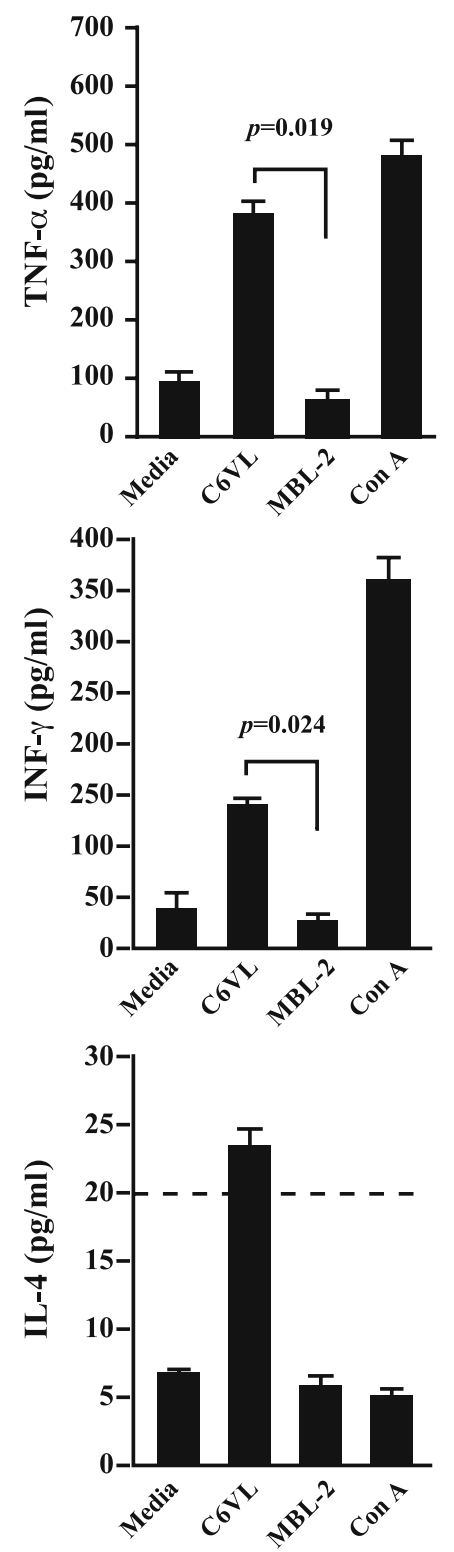

C6VL-DC+IL-15
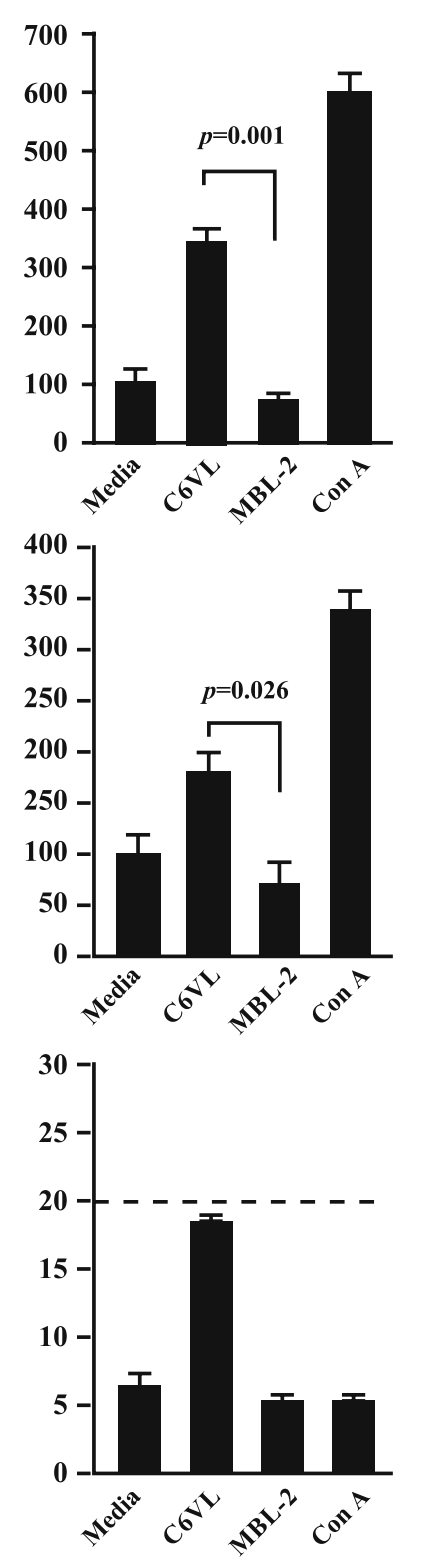

IL-15 adjuvant does not stimulate NK-mediated clearance of C6VL or augment the tumor-specific CTL activity stimulated by C6VL-DC vaccination of tumor-bearing mice

Overexpression of IL-15 in tumor-bearing hosts, expression of secretable IL-15 in tumor cells and injection of high doses of recombinant IL-15 protein have all been reported to stimulate NK-mediated clearance of tumors in vivo [24, 26, 44]. Culturing naïve splenocytes with $150 \mathrm{ng} / \mathrm{ml} \mathrm{rhIL-15}$ for $48 \mathrm{~h}$ resulted in LAK activity that efficiently lysed both C6VL and MBL-2 cells in vitro, while fresh splenocytes could efficiently lyse the NK-susceptible line, YAC-1, but not C6VL or MBL2 target cells (data not shown). To determine whether the dose of IL-15 that we administered in vivo over

Fig. 4 Interleukin-15 infusion does not increase vaccine-primed, tumor-specific cytokine release by DLN cells. Groups of five mice were vaccinated with C6VL-DC or HBSS and infused with rhIL-15 as described in Materials and methods. Eighteen hours following the last IL-15 infusion, DLN were harvested and stimulated for $72 \mathrm{~h}$ in vitro with mitomycin-C-treated C6VL or control tumor cells at a ratio of one tumor cell per five responder cells. Cytokine concentrations in culture supernatants were measured as described in the Materials and methods. Bars represent the mean of triplicate samples $\pm \mathrm{SD}$. The dotted line represents the assays lower limit of detection $(20 \mathrm{pg} / \mathrm{ml})$. $P$ values were calculated using a two sample Student's $t$ test. Cytokine secretion by mitomycin-C-treated tumor cells and DLN from recipients of only IL-15 or its diluent were below the limits of detection in all cases. Representative data from one of three independent experiments is shown

5 days was sufficient to generate LAK activity capable of killing C6VL in vitro, DLN and spleens from mice treated as described above were harvested, their cells pooled, and their ability to lyse C6VL and YAC-1 tumor cells was immediately assessed in a $16 \mathrm{~h}$ cytotoxicity assay. Pooled effector populations from tumor-bearing naïve mice demonstrated low but significant lysis of NKsusceptible YAC-1 targets (Fig. 5b), but were unable to lyse C6VL (Fig. 5a) $(P<0.0015$, lysis of C6VL compared to YAC-1). The level of YAC-1 lysis mediated by the naïve effectors was very similar to data previously reported by Kennedy et al. [15]. As expected based on our previous results [10], vaccination of mice with C6VL-DC did not increase NK lysis of C6VL compared to naïve effectors. Also, IL-15 treatment alone or in combination with C6VL-DC vaccines did not increase

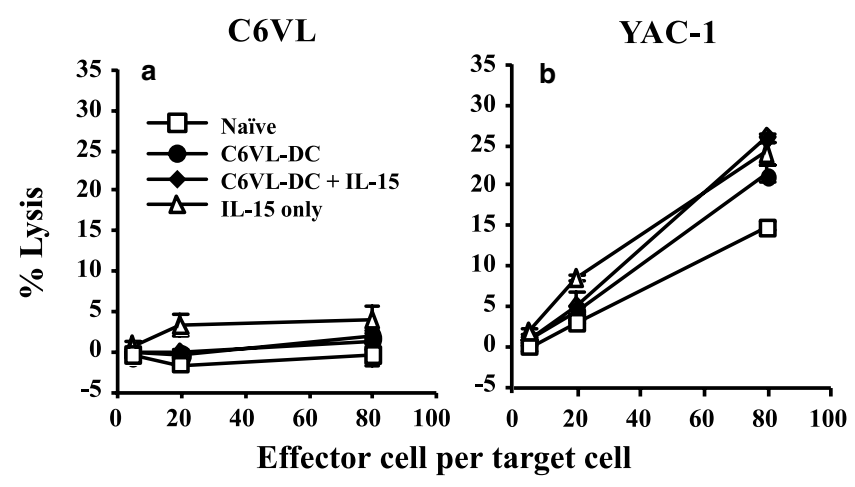

Fig. 5 Interleukin-15 infusions do not stimulate NK-mediated killing of C6VL. Six tumor-bearing mice per group were vaccinated with C6VL-DC or HBSS and infused with IL-15 as indicated in the Materials and methods. Mice were infused s.c. with $0.5 \mu \mathrm{g}$ rhIL-15 every $12 \mathrm{~h}$ for five consecutive days following each vaccine. Eighteen hours following the last IL-15 infusion, DLN and spleens were harvested, pooled and used immediately in an overnight CTL assay. Specific lysis of DiO-labeled C6VL (a) and NK-susceptible YAC-1 (b) tumor cells at E:T of 80:1, 20:1 and 5:1 were assessed by flow cytometry following a 16-h incubation of targets with effectors. Percent lysis was calculated as described in the Materials and methods. Data points represent the mean of duplicate samples \pm SD. Representative data from one of three independent experiments is shown 

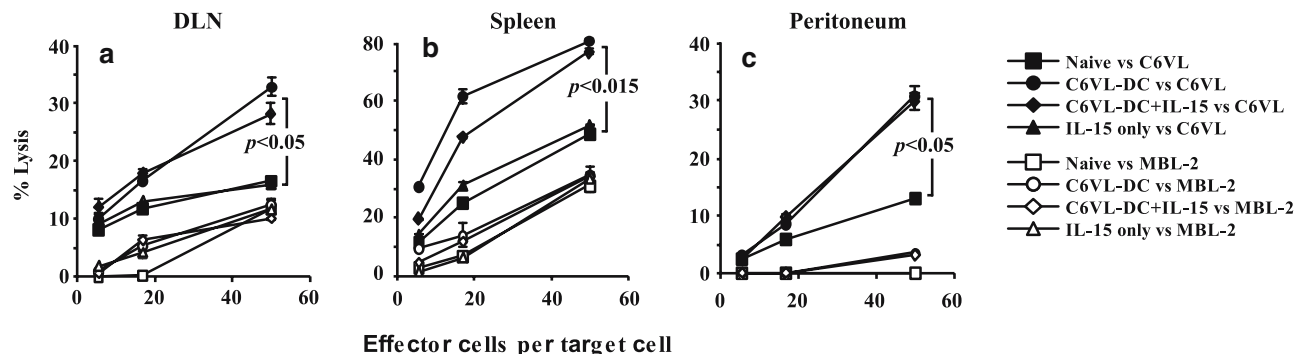

Fig. 6 Interleukin-15 does not augment the tumor-specific CTL activity stimulated by C6VL-DC vaccines in tumor-bearing mice. Six mice per group were vaccinated with C6VL-DC or HBSS and were given IL-15 or diluent only as detailed in the Materials and methods. Eighteen hours following the last IL-15 infusion, DLN, splenocytes and peritoneal lavage samples were harvested and restimulated in vitro for 5 days with one irradiated C6VL cell per five responder cells. Specific lysis of DiO-labeled C6VL and MBL-2 (control) tumor cells by (a), DLN; (b), splenocytes; or c, peritoneal lavage cells at E:T of 50:1, 17:1 and 5.6:1 was assessed by flow cytometry following a 4-h incubation of targets with restimulated effectors. Percent lysis was calculated as described in the Materials and methods. Data points represent the mean of duplicate samples \pm SD. $P$ values were calculated using a two sample Student's $t$ test at each data point. Representative data from one of two independent experiments is shown

the ability of the effectors to lyse C6VL cells (Fig. 5a, all $P>0.05$ ), indicating that the dose of IL-15 that we administered was insufficient to generate significant LAK activity in the DLN or spleen. Surprisingly, lysis of YAC-1 cells was not augmented by IL-15 treatment alone or in conjunction with C6VL-DC vaccines, despite increased numbers of NK cells in IL-15 recipients.

C6VL-specific CTL activities in the DLN, spleens and peritoneal cavity of treated mice was also measured. Incubation of target cells with restimulated DLN, splenocytes and peritoneal cells from C6VL-DC recipients resulted in high levels of killing of C6VL at all E:T ratios (Fig. 6a, b, c). The CTL activity was specific as MBL-2 target cells were killed at significantly lower levels than C6VL at all ratios $(P<0.0047, P<0.0047$ and $P<0.001$ for DLN, spleen and peritoneum, respectively). Likewise, cells harvested from recipients of C6VL-DC + IL-15 lysed C6VL efficiently compared to MBL-2 $(P<0.0024,<0.0032$ and $<0.001$ for DLN, splenocytes and peritoneal cells, respectively). However, despite increased numbers of activated or memoryphenotype $\mathrm{CD} 8^{+} \mathrm{T}$ cells in mice treated with C6VLDC + IL-15 compared to C6VL-DC alone, killing of C6VL tumor cells was not enhanced in mice infused with IL-15 (Fig. 6a, b, c). In vitro stimulation with C6VL likely gave rise to some specific CTL activity against C6VL in the cells isolated from the control treated mice. However, killing of C6VL by cells harvested from the DLN, spleen and peritoneum of C6VL-DC and C6VL$\mathrm{DC}+\mathrm{IL}-15$ recipients remained significant compared to the background killing of C6VL by cells in the control groups, with $P$ values of $<0.044,<0.015$ and $<0.05$ for all ratios in the DLN, spleen and peritoneum, respectively.

IL-15 infusion does not enhance the survival of tumorbearing C6VL lysate-pulsed DC vaccine recipients

Prior experiments have shown that C6VL lysate-pulsed $\mathrm{DC}$ vaccines are able to stimulate a protective immune response in mice bearing a lethal number of C6VL cells [10]. We looked to see if IL-15 infusions would enhance the efficacy of our C6VL-DC vaccine. Mice were tumor challenged and immunized three times with IL-15 given between each immunization. Mice receiving MBL-2-DC vaccines or only IL-15 were included as control groups. As expected, C6VL-DC vaccines significantly enhanced the survival of tumor-bearing mice compared to mice vaccinated with MBL-2-DC $(P=0.039)$, with $30 \%$ of the tumor-challenged mice surviving (Fig. 7). C6VL-DC vaccines coupled with IL-15 also significantly enhanced the survival of tumor-bearing mice compared to MBL-2$\mathrm{DC}+\mathrm{IL}-15$ recipients $(P=0.039)$. However, IL-15 infusion in addition to C6VL-DC vaccines did not augment the survival of mice compared to C6VL-DC vaccines alone $(P=0.72)$. None of the control treated groups survived the tumor challenge confirming our in vitro evidence that IL-15 infusion does not result in background clearance of the C6VL tumor. Modifying our dosing schedule to give the same $0.5 \mu \mathrm{g} / \mathrm{mouse}$ IL-15 every $12 \mathrm{~h}$, but for five consecutive days prior to the second and third vaccines, or for more prolonged peri-

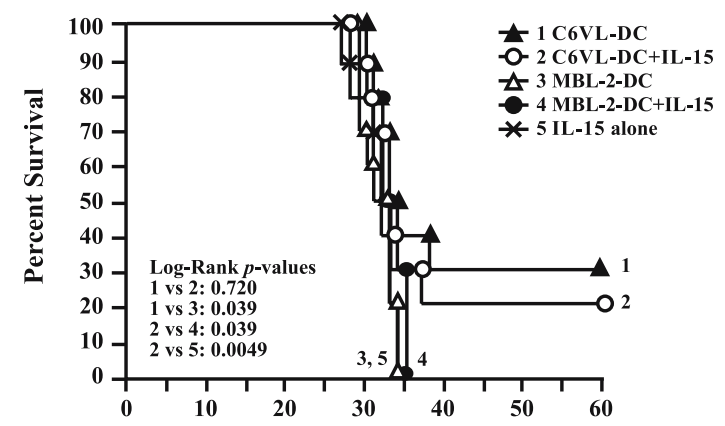

Fig. 7 Interleukin-15 infusion does not enhance the survival of tumor-bearing C6VL lysate-pulsed DC vaccine recipients. Naïve mice were challenged with a lethal dose of C6VL. Twenty-four hours following tumor challenge, mice received their first vaccine of $5.0 \times 10^{5}$ C6VL or MBL-2 lysate-pulsed DC. The vaccines continued every 10 days for three vaccines. Beginning $1 \mathrm{~d}$ following each vaccine and continuing every $12 \mathrm{~h}$ for 5 days, $0.5 \mu \mathrm{g}$ rhIL- 15 was administered s.c. at the vaccine site. Control mice receiving DC vaccines but not IL-15 were injected with diluent alone on the same schedule. The mice were monitored for survival for 60 days following tumor challenge 
ods (14 consecutive days, beginning 1 day following the first C6VL-DC vaccine) or giving the IL-15 i.p. at lower doses also failed to improve the efficacy of the C6VLDC vaccine (data not shown).

Failure of IL-15 infusion to enhance vaccine-primed clearance of C6VL in vivo is likely not due to vaccineprimed and IL-15 expanded cells being sequestered in the secondary lymphoid organs

Phenotypic characterization of the $\mathrm{CD}^{+} \mathrm{T}$ cells in the DLN of IL-15 recipients indicated that activated T cells with a phenotype characteristic of central memory $\mathrm{T}$ cells $\left(\mathrm{T}_{\mathrm{CM}}\right)$ comprised a significant proportion of all cells in the draining lymph nodes of mice receiving IL-15 in addition to the C6VL-DC vaccine (Fig. $3 b$ ). $\mathrm{T}_{\mathrm{CM}}$ home to secondary lymphoid organs due to their high levels of CCR7 and CD62L expression [37, 41] and lack immediate inflammatory and cytotoxic function. However, they can mediate rapid recall responses with greater potency against viral infections and established tumors than effector-phenotype $\mathrm{CD}^{+} \mathrm{T}$ cells $[19,42]$ when used for adoptive immunotherapy. Further, murine antigen-primed $\mathrm{CD} 8{ }^{+} \mathrm{T}$ cells cultured in IL-15 resemble $\mathrm{T}_{\mathrm{CM}}$ in phenotype and function, and thus require restimulation with antigen to acquire cytolytic function [22]. Based on this information, we were concerned that possibly C6VL-specific $\mathrm{T}_{\mathrm{CM}}$ in the DLN and peripheral lymphoid organs were not trafficking to tumor sites where they would be restimulated and acquire effector function $[22,41]$. It was also possible that our in vitro CTL assay was not sensitive enough to detect IL-15 induced differences in tumor-specific CTL activity, as the assay uses small numbers of cells per sample and the percent of $\mathrm{CD}^{+}$expansion was not as dramatic as the change in absolute numbers of cells. To address these concerns, we performed an in vivo CTL assay to compare both the C6VL-clearing capacity of an entire lymph node-equivalent of cells and the clearing capacity of a defined number of $\mathrm{CD} 8^{+} \mathrm{T}$ cells from C6VL-DC and C6VL-DC + IL-15 recipient mice. DLN cells from each group were injected i.p into mice bearing five times the lethal dose of C6VL cells in their peritoneum. Transfer of $3.2 \times 10^{6}$ DLN cells (equivalent to one DLN) pooled from ten C6VL-DC vaccinated mice resulted in significant protection of naïve tumor-bearing recipient mice compared to transfer of MBL-2-DC-primed DLN $(P=0.0022)$ (Fig. 8a, b). While the transfer of 1 DLN equivalent of cells from C6VL-DC + IL-15-treated mice $\left(6.7 \times 10^{6}\right.$ cells pooled from 13 mice $)$ also resulted in significant protection of naïve recipient mice compared to the transfer of an equal number of cells from mice treated with MBL-2-DC+IL-15 $(P<0.001)$, the protection was not increased compared to transfer of cells primed with C6VL-DC alone $(P>0.92)$ (Fig. 8a). Further, the transfer of a $\mathrm{CD} 8^{+} \mathrm{T}$ cell-matched number of DLN $\left(1.7 \times 10^{6}\right.$ total cells or $\left.5.9 \times 10^{5} \mathrm{CD} 8^{+}\right)$primed with C6VL-DC+ IL-15 did not confer significant protection

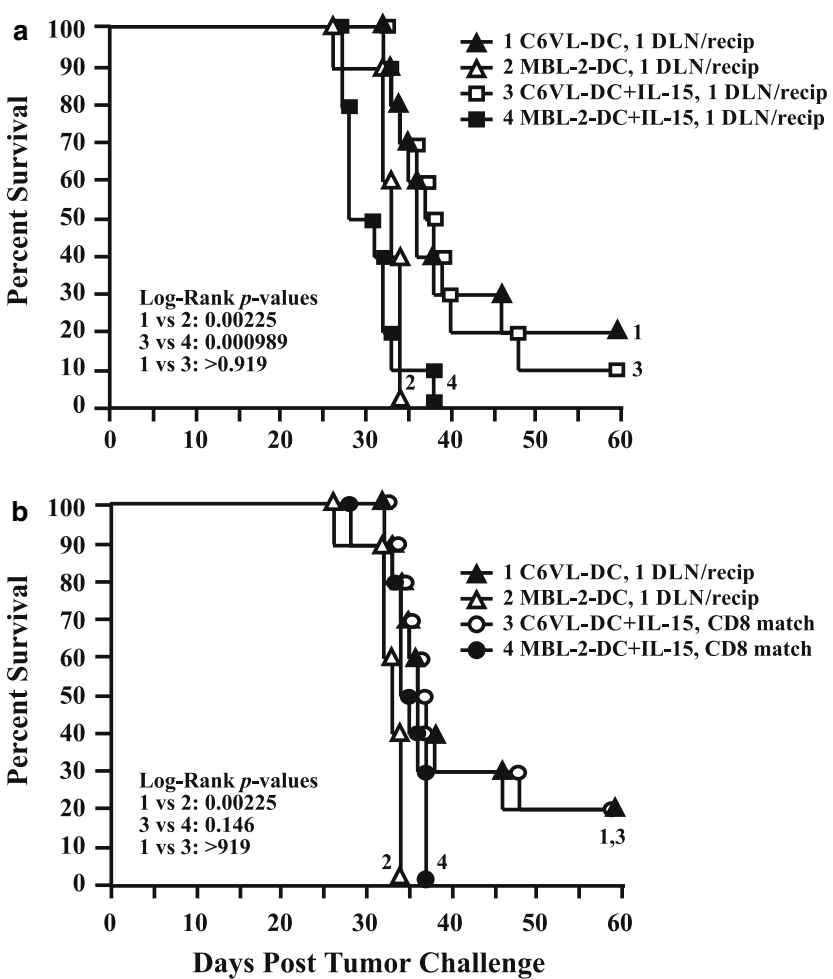

Fig. 8 C6VL-DC + IL-15 recipients do not have enhanced C6VLspecific CTL activity per-DLN or per-CD8 ${ }^{+} \mathrm{T}$ cell compared to recipients of C6VL-DC vaccines alone. Tumor-bearing donor mice $\left(n=13\right.$ per group) were vaccinated twice with $5.0 \times 10^{5}$ C6VL- or MBL-2-lysate-pulsed DC and infused s.c. with $0.5 \mu \mathrm{g}$ rhIL-15 twice daily for 5 days following each vaccine. Mice vaccinated with C6VL-DC or MBL-2-DC without IL-15 infusion ( $n=11$ per group) were control donors. Eighteen hours following the last IL-15 infusion, DLN from each group were harvested, pooled, mixed with C6VL cells and injected into the peritoneum of ten naïve recipient mice per group. Each naïve recipient received 5000 C6VL cells and either a number of cells equivalent to one donor's DLN $\left(3.2 \times 10^{6}\right.$, C6VL-DC and MBL-2-DC DLN; or $6.7 \times 10^{6}$, C6VLDC+ IL-15 and MBL-2-DC+ IL-15 DLN) or b a number of cells from IL-15 recipient DLN that resulted in the transfer of a number of $\mathrm{CD}^{+}{ }^{+} \mathrm{T}$ cells that matched those transferred in 1 DLN from C6VL-DC and MBL-2-DC donors $\left(1.7 \times 10^{6}\right.$ total cells or $5.9 \times 10^{5}$ $\mathrm{CD}^{+}$per recipient)

compared to transfer of the same number of MBL-2DC + IL-15-primed DLN cells $(P=0.146)($ Fig. 8b).

\section{Discussion}

Our laboratory previously demonstrated that vaccination of tumor bearing mice with lysate-pulsed DC stimulated potent $\mathrm{CD} 8^{+} \mathrm{T}$ cell-mediated clearance of C6VL, and resulted in an average of $40 \%$ survival [10]. While the use of IL-15 as a vaccine adjuvant has been reported to enhance the antitumor activity of adoptively transferred $\mathrm{CD} 8{ }^{+} \mathrm{T}$ cells transgenic for tumor antigens [19, 35], the ability of IL-15 to augment vaccine-primed responses by endogenous wild-type $\mathrm{CD} 8^{+} \mathrm{T}$ cells has not been assessed in a therapeutic tumor model. We hypothesized that the administration 
of IL-15 in conjunction with C6VL-DC vaccines would enhance vaccine-primed $\mathrm{CD} 8^{+} \mathrm{T}$ cell immunity against C6VL and thus result in higher levels of survival in our therapeutic model. Instead, we found that IL-15 administration neither helped nor hindered C6VL-DCprimed $\mathrm{T}$ cell responses against $\mathrm{C} 6 \mathrm{VL}$ or the survival of tumor-bearing mice. Our collective data indicates that while IL-15 infusion following C6VL-DC vaccines resulted in dramatic expansion of NK, NKT and activated $\mathrm{CD} 8{ }^{+} \mathrm{T}$ cells at both local (DLN, Figs. 2 and 3a) and distal sites (CLLN and spleen; data not shown), $\mathrm{T}$ cells with specificity for C6VL were not significantly or preferentially expanded by the treatment (Figs. 4, 6, 7, 8).

Recent studies of systemic IL-15 administration in adoptive transfer models demonstrated that systemic administration of IL-15 augmented the primary antigenspecific $\mathrm{CD} 8{ }^{+} \mathrm{T}$ cell response following a peptide-pulsed DC vaccine [35] and potentiated the in vivo tumor activity of antigen-specific CD8 ${ }^{+} \mathrm{T}$ cells [18]. However, these studies monitored antigen-specific responses of transgenic $\mathrm{CD} 8^{+} \mathrm{T}$ cells following the transfer of a relatively large number $\left(1.0-5.0 \times 10^{6}\right)$ of splenocytes or purified $\mathrm{CD} 8{ }^{+} \mathrm{T}$ cells that were activated in vivo by vaccination $[19,35]$. Thus, the inability of IL-15 to enhance survival in our tumor model may be due to naïve mice having comparably few resident tumor specific $\mathrm{CD} 8{ }^{+} \mathrm{T}$ cells that are available for stimulation by our DC vaccines and expansion by IL-15. Similarly, Oh et al. [28] recently reported that IL-15 only slightly increased the frequency of antigen specific $\mathrm{CD} 8^{+} \mathrm{T}$ cells primed by HIV vaccine vectors in wild-type mice.

It is possible that using a different IL-15 administration schedule, route or timing relative to the DC vaccine may be more efficacious. Our administration of IL-15 is similar, but not exactly the same as that reported by others. Rubinstein et al. [35] reported that one round of IL-15 infusion $(0.5 \mu \mathrm{g} /$ mouse every $12 \mathrm{~h}, \times 7$ days) following a single vaccination with OVA peptide-pulsed DC enhanced the primary antigen-specific response of adoptively transferred OT-1 CD $8^{+} \mathrm{T}$ cells. We also administered $0.5 \mu \mathrm{g}$ IL-15 every $12 \mathrm{~h}$, but for 5 days following each of two vaccines. While many groups have reported biological activity with $0.5 \mu \mathrm{g}$ IL-15 twice daily, doses as high as $108 \mu \mathrm{g}$ twice daily for 3 days have been used in other murine models [19], with the strong caveat that many manuscripts published on the topic have not included the specific activity of the recombinant IL-15 used in the studies. We chose to deliver the IL-15 s.c. at the site of DC vaccines instead of i.p., as has been traditionally done. This avoids administering the IL-15 to the same site as the tumor (i.p.) and potentially biases expansion and survival of vaccine-primed $\mathrm{CD} 8^{+} \mathrm{T}$ cells in the DLN. The rational for administering the IL-15 at the vaccine site is further supported by recently published studies by Dubois et al. [6] showing that the IL-15R $\alpha$ chain functions to cross-present IL-15 from antigenpresenting cells to $\mathrm{T}$ cells. Importantly, injecting IL-15 s.c. still resulted in expansion of $\mathrm{T}$ cells at distal sites in vivo, indicating that our dose was sufficient to induce systemic effects. Several other schedules and amount of IL-15 were tried in our model without any significant improvement in vaccine efficacy.

We used recombinant human IL-15 in our studies, as many groups studying the in vivo and in vitro effects of IL-15 have done. While doing so risks raising antihuman IL-15 antibodies in vivo, we were unable to detect IL-15specific antibodies by ELISA in any of the sera from 36 individual IL-15-treated mice used in three independent experiments (assayed 10 days following the last IL-15 infusion; data not shown). Also, while IL-15 supports the growth and survival of some human malignant T cell lines in vitro [33, 45], culturing C6VL for $96 \mathrm{~h}$ in the presence of up to $1 \mu \mathrm{g} / \mathrm{ml}$ IL-15 did not influence the proliferation rate or viability of the C6VL cells (data not shown) nor did it hasten the demise of tumor challenged mice (Fig. 7). Finally, while it was recently noted that IL-15 can expand de novo-induced human antigen-specific regulatory $\mathrm{CD} 4^{+} \mathrm{T}$ cells in the presence of cognate antigen, $\mathrm{CD} 25^{+} \mathrm{CD} 4^{+}$T cells were not expanded by IL15 infusion in our studies (data not shown), nor do we have evidence that regulatory $\mathrm{T}$ cells specific for $\mathrm{C} 6 \mathrm{VL}$ antigens are induced by vaccination against, or tumor challenge with, C6VL (data not shown). These results are in line with previously published data showing that IL-15 stimulates little, if any, proliferation of murine $\mathrm{CD}^{+} \mathrm{T}$ cells [46].

We did not find that IL-15 enhanced tumor specific cytokine secretion or CTL activity in DLN, CLLN or spleen cells harvested 6 days following the second DC vaccine. It is possible that due to the timing of our analysis or the in vitro assays that we used, some $\mathrm{CD} 8{ }^{+} \mathrm{T}$ cell responses were augmented by IL-15 and went undetected. Others have detected augmented in vitro CTL activity among transgenic $\mathrm{CD} 8^{+} \mathrm{T}$ cells as early as 6 days following a single peptide-pulsed DC vaccine when rhIL-15 was administered using the same dose and time schedule that we used. However, they did not assess the in vivo tumor clearing capacity of the cells [35]. In another study using the same model, IL-15 without concomitant DC vaccination increased the number of antigen-reactive $\mathrm{T}$ cells without improving the overall survival of the treated mice [25]. While these studies showed that IL-15 expanded early responses of antigen-specific $\mathrm{CD} 8^{+} \mathrm{T}$ cells, Oh et al. [28] showed that the utility of IL-15 as adjuvant for vaccination against HIV antigens was the induction of longer-lived $\mathrm{CD} 8{ }^{+} \mathrm{T}$ cell immunity in vaccine recipients, suggesting that IL-15 during priming may alter the quality rather than just the quantity of $\mathrm{CD} 8^{+} \mathrm{T}$ cells during the immune-induction phase. As our analysis did not correlate the immunophenotype of a cell to its response upon restimulation by C6VL, we cannot say what proportion of the CTL responses that we measured were mediated by primary effector versus early memory $\mathrm{CD} 8^{+} \mathrm{T}$ cells primed by the C6VL-DC vaccines, or whether IL-15 infusion changed the 
amount of cytokine a single cell type secretes upon tumor recognition. We were consistently unable to demonstrate any augmented antitumor immune response among mice receiving IL-15 in addition to C6VL-DC vaccine. If any augmented responses went undetected by our in vitro analysis, they were not of sufficient magnitude to positively affect the survival of C6VL-bearing mice.

Interleukin-15, indeed, has many attributes that make it an attractive choice for use as a vaccine adjuvant to augment $\mathrm{CD}^{+}{ }^{+} \mathrm{T}$ cell responses. While our results do not support its use to enhance a primary antitumor immune response, it might be very effective in enhancing recall responses or to bolster $\mathrm{CD}^{+} \mathrm{T}$ cell responses following adoptive transfer of tumor-specific $\mathrm{T}$ cells. We believe that further elucidation of the kinetics of $\mathrm{CD} 8^{+}$ $\mathrm{T}$ cell primary responses and memory cell development following vaccination against tumor antigen, and how they are affected by the presence or absence of tumor in vivo, will help investigators use IL-15 to its fullest adjuvant potential in models of active immunotherapy.

Acknowledgements This work was supported in part by the Office of Research and Development, Medical Research Service, Department of Veterans Affairs and a G\& P Medical Research Award. E.G. was supported by National Institute of Allergy and Infectious Diseases Training Grant T32AI07413 and by National Cancer Institute Training Grant T32CA88784. The IL-15 was kindly provided by Amgen Corporation. Many thanks to Dr. James Ferrara for his careful review of this manuscript.

\section{References}

1. Barth RJ, Mule' JJ (2000) Interleukin-2: preclinical trials. In: Rosenberg SA (eds) Principles and practice of the biologic therapy of cancer. Lippincott Williams\& Wilkins, Philadelphia, pp 19-31

2. Berard M, Brandt K, Bulfone-Paus S, Tough DF (2003) IL-15 promotes the survival of naive and memory phenotype CD8+ T cells. J Immunol 170:5018-5026

3. Brentjens RJ, Latouche JB, Santos E, Marti F, Gong MC, Lyddane C, King PD, Larson S, Weiss M, Riviere I, Sadelain M (2003) Eradication of systemic B cell tumors by genetically targeted human T lymphocytes co-stimulated by CD80 and interleukin-15. Nat Med 9:279-286

4. Bulfone-Pau SS, Bulanova E, Pohl T, Budagian V, Durkop H, Ruckert R, Kunzendorf U, Paus R, Krause H (1999) Death deflected: IL-15 inhibits TNF-alpha-mediated apoptosis in fibroblasts by TRAF2 recruitment to the IL-15Ralpha chain. Faseb J 13:1575-1585

5. Dallal RM, Mailliard R, Lotze MT (2000) Cancer vaccines: clinical applications, dendritic cell vaccines. In: Rosenberg SA (eds) Principles and practice of the biologic therapy of cancer. Lippincott Williams\& Wilkins, Philadelphia, pp 705

6. Dubois S, Mariner J, Waldmann TA, Tagaya Y (2002) IL$15 \mathrm{R} \alpha$ recycles and presents IL-15 in trans to neighboring cells. Immunity 17:537-547

7. Fehniger TA, Suzuki K, Ponnappan A, VanDeusen JB, Cooper MA, Florea SM, Freud AG, Robinson ML, Durbin J, Caligiuri MA (2001) Fatal leukemia in interleukin 15 transgenic mice follows early expansions in natural killer and memory phenotype CD8 + T cells. J Exp Med 193:219-231

8. Fehniger TA, Suzuki K, VanDeusen JB, Cooper MA, Freud AG, Caligiuri MA (2001) Fatal leukemia in interleukin-15 transgenic mice. Blood Cells Mol Dis 27:223-230
9. Fields RC, Shimizu K, Mule JJ (1998) Murine dendritic cells pulsed with whole tumor lysates mediate potent antitumor immune responses in vitro and in vivo. Proc Natl Acad Sci USA 95:9482-9487

10. Gatza E, Okada CY (2002) Tumor cell lysate-pulsed dendritic cells are more effective than TCR Id protein vaccines for active immunotherapy of T cell lymphoma. J Immunol 169:5227-5235

11. Grabstein KH, Eisenman J, Shanebeck K, Rauch C, Srinivasan S, Fung V, Beers C, Richardson J, Schoenborn MA, Ahdieh M et al (1994) Cloning of a T cell growth factor that interacts with the beta chain of the interleukin-2 receptor. Science 264:965-968

12. Hart DN, Hill GR (1999) Dendritic cell immunotherapy for cancer: application to low-grade lymphoma and multiple myeloma. Immunol Cell Biol 77:451-459

13. Judge AD, Zhang X, Fujii H, Surh CD, Sprent J (2002) Interleukin 15 controls both proliferation and survival of a subset of memory-phenotype CD8(+) T cells. J Exp Med 196:935-946

14. Kaplan EL, Meiier P (1958) Nonparametric estimation from incomplete observations. J Am Stat Assoc 53:475

15. Kennedy MK, Glaccum M, Brown SN, Butz EA, Viney JL, Embers M, Matsuki N, Charrier K, Sedger L, Willis CR, Brasel K, Morrissey PJ, Stocking K, Schuh JC, Joyce S, Peschon JJ (2000) Reversible defects in natural killer and memory CD8 T cell lineages in interleukin 15-deficient mice. J Exp Med 191:771-780

16. Khan IA, Casciotti L (1999) IL-15 prolongs the duration of CD8 ${ }^{+} \mathrm{T}$ cell-mediated immunity in mice infected with a strain of Toxoplasma gondii. J Immunol 163:4503

17. Kiessling R, Klein E, Pross H, Wigzell H (1975) "Natural" killer cells in the mouse. II. Cytotoxic cells with specificity for mouse Moloney leukemia cells. Characteristics of the killer cell. Eur J Immunol 5:117-121

18. Kiessling R, Klein E, Wigzell H (1975) "Natural" killer cells in the mouse. I. Cytotoxic cells with specificity for mouse Moloney leukemia cells. Specificity and distribution according to genotype. Eur J Immunol 5:112-117

19. Klebanoff CA, Finkelstein SE, Surman DR, Lichtman MK, Gattinoni L, Theoret MR, Grewal N, Spiess PJ, Antony PA, Palmer DC, Tagaya Y, Rosenberg SA, Waldmann TA, Restifo NP (2004) IL-15 enhances the in vivo antitumor activity of tumor-reactive CD8 + T Cells. Proc Natl Acad Sci USA 101:1969-1974

20. Kobayashi H, Carrasquillo JA, Paik CH, Waldmann TA, Tagaya Y (2000) Differences of biodistribution, pharmacokinetics, and tumor targeting between interleukins 2 and 15. Cancer Res 60:3577-3583

21. Ku CC, Murakami M, Sakamoto A, Kappler J, Marrack P (2000) Control of homeostasis of CD8 + memory T cells by opposing cytokines. Science 288:675-678

22. Manjunath N, Shankar P, Wan J, Weninger W, Crowley MA, Hieshima K, Springer TA, Fan X, Shen H, Lieberman J, von Andrian UH (2001) Effector differentiation is not prerequisite for generation of memory cytotoxic T lymphocytes. J Clin Invest 108:871-878

23. Marks-Konczalik J, Dubois S, Losi JM, Sabzevari H, Yamada N, Feigenbaum L, Waldmann TA, Tagaya Y (2000) IL-2-induced activation-induced cell death is inhibited in IL-15 transgenic mice. Proc Natl Acad Sci USA 97:11445-11450

24. Meazza R, Lollini PL, Nanni P, De Giovanni C, Gaggero A, Comes A, Cilli M, Di Carlo E, Ferrini S, Musiani P (2000) Gene transfer of a secretable form of IL-15 in murine adenocarcinoma cells: effects on tumorigenicity, metastatic potential and immune response. Int $\mathbf{J}$ Cancer 87:574-581

25. Moroz A, Eppolito E, Li Q, Tao J, Clegg CH, Shrikant P (2004) IL-21 enhances and sustains CD8 $+\mathrm{T}$ cell responses to achieve durable tumor immunity: comparative evaluation of IL-2, IL-15, and IL-21. J Immunol 173:900-909

26. Munger W, DeJoy SQ, Jeyaseelan R Sr, Torley LW, Grabstein $\mathrm{KH}$, Eisenmann J, Paxton R, Cox T, Wick MM, Kerwar SS (1995) Studies evaluating the antitumor activity and toxicity of 
interleukin-15, a new $\mathrm{T}$ cell growth factor: comparison with interleukin-2. Cell Immunol 165:289-293

27. O'Neill HC (1991) Radiation leukemia virus-induced T cell lymphomas with common $\mathrm{T}$ cell receptor variable region structure and similar binding specificity for retrovirus. Leukemia 5:921

28. Oh S, Berzofsky JA, Burke DS, Waldmann TA, Perera LP (2003) Coadministration of HIV vaccine vectors with vaccinia viruses expressing IL-15 but not IL-2 induces long-lasting cellular immunity. Proc Natl Acad Sci USA 100:3392-3397

29. Okada CY, Wong CP, Denney DW, Levy R (1997) TCR vaccines for active immunotherapy of $\mathrm{T}$ cell malignancies. $\mathrm{J}$ Immunol 159:5516-5527

30. Peto R, Peto J (1972) Asymptomatically efficient rank invariant test procedures. J R Stat Soc 135:185

31. Piriou L, Chilmonczyk S, Genetet N, Albina E (2000) Design of a flow cytometric assay for the determination of natural killer and cytotoxic T-lymphocyte activity in human and in different animal species. Cytometry 41:289-297

32. Prlic M, Lefrancois L, Jameson SC (2002) Multiple choices: regulation of memory $\mathrm{CD} 8 \mathrm{~T}$ cell generation and homeostasis by interleukin (IL)-7 and IL-15. J Exp Med 195:F49-F52

33. Qin J, Zhang C, Kamarashev J, Dummer R, Burg G, Dobbeling $U$ (2001) Interleukin-7 and interleukin-15 regulate the expression of the $b c l-2$ and $c-m y b$ genes in cutaneous $\mathrm{T}$ cell lymphoma cells. Blood 98:2778-2783

34. Rosenberg SA, Yang JC, Schwartzentruber DJ, Hwu P, Marincola FM, Topalian NP, Restifo NP, Dudley ME, Schwarz SL, Spiess P, al e (1998) Immunologic and therapeutic evaluation of a synthetic peptide vaccine for the treatment of patients with metastatic melanoma. Nat Med 4:321

35. Rubinstein MP, Kadima AN, Salem ML, Nguyen CL, Gillanders WE, Cole DJ (2002) Systemic administration of IL-15 augments the antigen-specific primary CD8 $+\mathrm{T}$ cell response following vaccination with peptide-pulsed dendritic cells. J Immunol 169:4928-4935

36. Ruedl C, Rieser C, Bock G, Wick G, Wolf H (1996) Phenotypic and functional characterization of $\mathrm{CD} 11 \mathrm{c}+$ dendritic cell population in mouse Peyer's patches. Eur J Immunol 26:18011806
37. Sallusto F, Lenig D, Forster R, Lipp M, Lanzavecchia A (1999) Two subsets of memory $T$ lymphocytes with distinct homing potentials and effector functions. Nature 401:708-712

38. Schluns KS, Lefrancois L (2003) Cytokine control of memory $\mathrm{T}$ cell development and survival. Nat Rev Immunol 3:269-279

39. Schwartzentruber DJ (2001) Guidelines for the safe administration of high-dose interleukin-2. J Immunother 24:287

40. Waldmann TA, Dubois S, Tagaya Y (2001) Contrasting roles of IL-2 and IL-15 in the life and death of lymphocytes: implications for immunotherapy. Immunity 14:105-110

41. Weninger W, Crowley MA, Manjunath N, von Andrian UH (2001) Migratory properties of naive, effector, and memory CD8(+) T cells. J Exp Med 194:953-966

42. Wherry EJ, Teichgraber V, Becker TC, Masopust D, Kaech SM, Antia R, von Andrian UH, Ahmed R (2003) Lineage relationship and protective immunity of memory CD8 $\mathrm{T}$ cell subsets. Nat Immunol 4:225-234

43. Yajima $T$, Nishimura $H$, Ishimitsu $R$, Watase $T$, Busch $D H$, Pamer EG, Kuwano H, Yoshikai Y (2002) Overexpression of IL-15 in vivo increases antigen-driven memory CD8 + T cells following a microbe exposure. J Immunol 168:1198-1203

44. Yajima T, Nishimura H, Wajjwalku W, Harada M, Kuwano $\mathrm{H}$, Yoshikai Y (2002) Overexpression of interleukin-15 in vivo enhances antitumor activity against MHC class I-negative and -positive malignant melanoma through augmented NK activity and cytotoxic $\mathrm{T}$ cell response. Int $\mathrm{J}$ Cancer 99:573-578

45. Yamada N, Sugawara I, Hata T, Tsuruta K, Moriuchi R, Maeda T, Atogami S, Murata K, Fujimoto K, Kohno T, Tsukasaki K, Tomonaga M, Hirakata Y, Kaminihira S (1998) Interleukin-15 (IL-15) can replace the IL-2 signal in IL-2dependent adult T cell leukemia (ATL) cell lines: expression of IL-15 receptor $\alpha$ on ATL cells. Blood 91:4265-4272

46. Zhang X, Sun S, Hwang I, Tough DF, Sprent J (1998) Potent and selective stimulation of memory-phenotype CD $8+\mathrm{T}$ cells in vivo by IL-15. Immunity 8:591-599 